\title{
Waste utilization of fruits and vegetables-A review
}

\author{
P.K. Omre ${ }^{1}$, Shikhangi Singh ${ }^{1}$, Shikha ${ }^{2}$ \\ ${ }^{1}$ Department of Post Harvest Process and Food Engineering, G.B. Pant University Of Agriculture \& \\ Technology, Pantnagar 263145, India \\ ${ }^{2}$ Project Fellow, Department of Home Science Extension, college of Home Science, G.B. Pant University \\ of Agriculture and Technology, Pantnagar, Uttarakhand, India
}

Email: shikhangisingh16@gmail.com

\begin{abstract}
Fruits and vegetables wastes occur throughout the supply chain and vary widely depending on its processing. The fruit and vegetable processing industries generated $10-60 \%$ waste or by-products in both solid and liquid form. Waste material should be utilized in such a manner that best possible benefits can be extracted without any monetary loss or environmental hazards. So, waste materials obtained from these industries can be utilized for composting and landfill by aerobic or anaerobic treatment, biogas production, animal feed and production of value added products. As fruits \& vegetables are perishable, their wastes get rotten quickly. So, waste disposal is a serious problem as it causes flies and rats around. Generation of renewable energy by bioconversion of fruits and vegetables waste is gaining importance as it has proved to be a proficient means of utilizing the perishable vegetable residues. Currently, livestock is one of the fastest growing agricultural subsectors in developing countries. Recent evidence shows that fruits and vegetables processing co-products can be effectively used in farm animal's nutrition as function feed ingredients. The present article deals with the studies conducted on fruits and vegetables for their utilization with various methods.
\end{abstract}

Keywords: Fruits and vegetable waste, anaerobic digestion, essential oil.

Paper cited: Omre, P.K., Singh, S. and Shikha (2018). Waste utilization of fruits and vegetables-A review. South Asian Journal of Food Technology and Environment, 4(1): 605-615

\section{Introduction}

Food processing is an important sector in agriculture, the scope of which has increased manifold that can help to prevent wastage of perishable commodities to a great extent. Fruits and vegetable wastes (FVW) are produced in large quantities in markets and constitute a source of nuisance in municipal landfills because of their high biodegradability. The production, processing and preparation of food, all results in generation of huge quantity of waste material causing health hazards due to environmental pollution. India is the second largest producer of fruits in the world and accounts for about $12 \%$ of the total world fruit production (FAO, 2010). Globally, the production of fruits and vegetables is about 675 million metric tons annually and out of which 1.3 billion ton wastage is produced. India alone produces 86.602 million metric tons of fruits and vegetables and constitute about 5.6 million ton of waste annually. Currently, these wastes are disposed of by dumping on the outskirts of cities. The huge wastage of the food material is due to lack of control on food processing industries and agri-economy practices. The Production (MT) statistics for some important fruits in India and the world is given in Table 1. 
Table 1: Production (MT) statistics for some important fruits in India and the world

\begin{tabular}{|l|c|c|}
\hline \multicolumn{1}{|c|}{ Crop } & India & World \\
\hline Bananas & 26.2 & 93.3 \\
Mangoes & 13.64 & 34.89 \\
Citrus fruits & 7.16 & 124.57 \\
Grapes & 1.73 & 66.64 \\
Watermelon & 0.25 & 98.4 \\
Pineapple & 1.30 & 19.26 \\
\hline Total fruits & 68.35 & 587.67 \\
\hline
\end{tabular}

\section{Composting and landfill}

Proper disposal of waste material is becoming an issue which all industrialists confronts, especially those settled in cities, where the land cost is very high. According to Times of India, published on September 6, 2017. "In Gurugram, plumes of smoke rising from padding fields on the disposal of waste material has become a challenge to the processors, as different agencies are pressurizing for an city's fringes and smog covering the skies in winter for the realization on toxic effects of agriculture and horticulture waste on the environment to hit home.

A rough estimate would put the city's horticulture waste-including flowers, leaves, fruits, and vegetables peel from households and the vegetable mandis at 400 tonnes, i.e. $40 \%$ of the 1000 tonnes of solid waste generated daily."

Therefore, composting is one of the best methods for solving the problems of waste materials disposal. This can be done by using different methods like natural weathering, aerobic and anaerobic processes in pits for a period of 12-18 months. The manure prepared after composting is ready to use for crop cultivation. The spent mushroom substrate can be utilized as organic manure which includes its utilization for nutritionally poor soil, neutralizing acidic soils and in other cases for improving polluted sites.

Vermi-composting is also viable alternative for utilization of the waste material. Leaves of the fruits, vegetables and floricultural crops can also be utilized in a similar way for purpose of composting and vermin-composting. The process of composting helps in prevention in spread of the insects/disease to the nearly crop or processing plant. So, after composting or vermin-composting process, the resultant material can be use for process, the resultant material can be use for landfilling in such a place where the soil/land is completely barren.
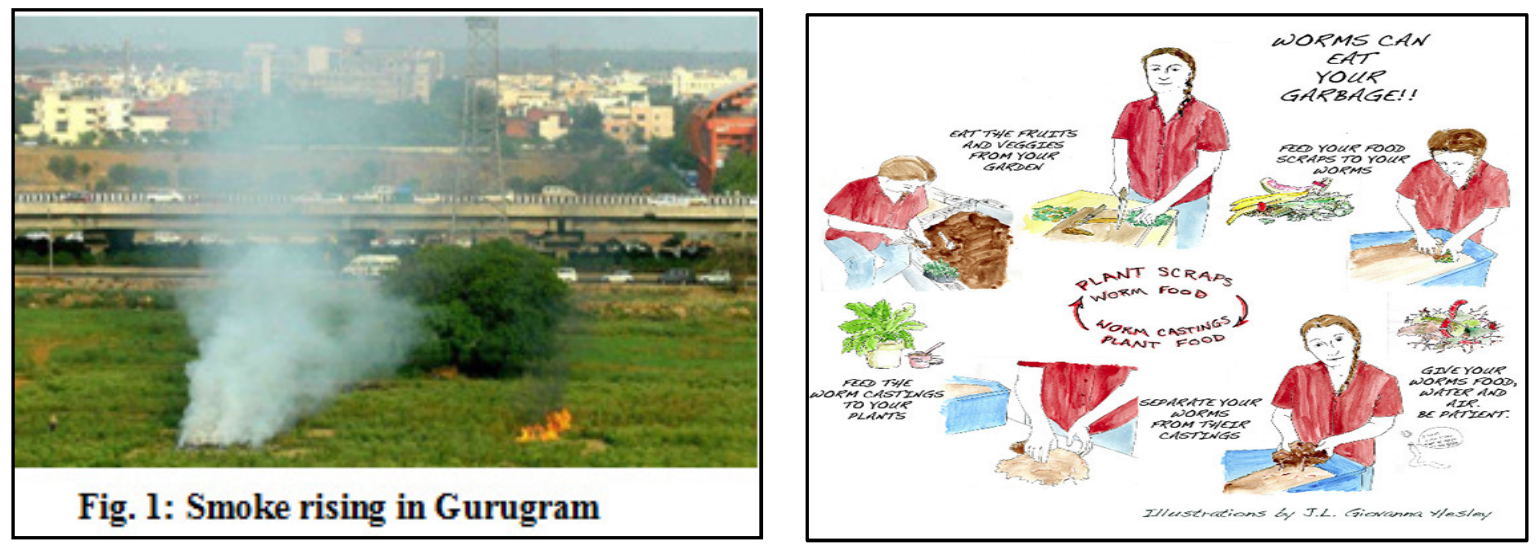

South Asian J. Food Technol. Environ., 4(1): 605-615 (2018) 
Table 2: Percentage of food waste and by products in fruits and vegetables production

\begin{tabular}{|l|c|}
\hline \multicolumn{1}{|c|}{ Production process } & Waste and by-product (\%) \\
\hline White wine production & $20-30$ \\
Red wine production & $20-30$ \\
Fruit and vegetable juice production & $30-50$ \\
Fruit and vegetable processing and preservation & $5-30$ \\
Vegetable oil production & $40-70$ \\
Sugar production from sugar beets & 85 \\
\hline
\end{tabular}

(Source: De Las Fuentes, et al, 2004)

The 12-18 months composting of the waste material results in increase NPK content, water holding capacity, organic carbon, etc and thereby can increase the soil fertility.

\section{Biogas}

About 750000 tonnes of fruit and vegetable wastes are produced each year by Australian canneries and juice-processors. Dr. Alan Lane of CSIRO division of food research, calculates that processing plant with an annual output of 30000 tonnes of waste (with 90\% moisture content) could generate 1.5 million cubic meters of gas a per year. At a pilot plant be designed at the Lerona Cooperative Cannery, the digester is producing 30-40 cubic meters of gas per day. These materials are usually high in fiber content and are of different sizes and forms. Three fourth of the total solids present are volatile solids. Their biodegradability varies accordingly with the state of hardening and kind of waste material. Carbon to nitrogen ratio varies in each vegetable, however for mixed variety it may be around 1:20 to 1:30. The origin of biogas is traced back to the Persians. They discovered that organic matter such as rotting vegetables gave a flammable gas that could be used for other purposes.

Anaerobic digestion of sorted organic wastes from municipal solid waste (MSW) especially food waste is a cost effective technology (Baere, 2000). Methane fermentation is a complex process. The general process of anaerobic digestion is a series of processes like enzymatic hydrolysis, acidogenesis, acetogenesis and methanogenesis (Veeken et al., 2000) and each metabolic stage is assisted by a series of micro organisms. Amongst the four stages, hydrolysis is the rate limiting stage for FVW (Vavilin et al., 1996, Christ et al., 2000).

The acid forming microbes convert macromolecules like carbohydrates, proteins, starches, cellulose etc to organic acids (step 1 and 2). In the 3rd step, organic acids are converted to acetate \& finally in the 4 th step the acetate is converted to $\mathrm{CH} 4$ and $\mathrm{CO} 2$ by the methanogens. The time needed for step 1 and 2 is more and this consumes most of the time. Carbohydrate rich substrates like FVW are quicker producers of volatile fatty acids (VFAs) (Mata et al., 2000) and leads to excess acid accumulation leading to acidity, low $\mathrm{pH}$ and process inhibition. So, higher concentration of substrates for FVW leads to lowering of $\mathrm{pH}$ and thereby produces less biogas.

Normally, biogas is composed of 45 $70 \%$ methane, $30-45 \%$ carbon dioxide, $0.5-1.0 \%$ hydrogen sulphide, 1-5\% water vapour, and a small amount of other gases (hydrogen, ammonia, nitrogen, etc.) (Uzodinma et al., 2011). Composition of a particular biofuel varies with the source and the concoction of biodegradable biomass (Wantanee and Sureelak, 2004). The potential of biogenic waste for gas production depends highly on its nature and 
biochemical composition (Sagagi et al., 2009). Waste sample have been characterized and

Table 3: Characterization of waste samples

\begin{tabular}{|c|c|}
\hline Parameters & Results \\
\hline Moisture Content(\%) & 8.51 \\
\hline Volatile Matter(\%) & 77.16 \\
\hline Ash(\%) & 7.07 \\
\hline Fixed Carbon(\%) & 7.25 \\
\hline Calorific Value (Cals/Gm) & 1913.4 \\
\hline C:H:N & $83: 12: 5$ \\
\hline
\end{tabular}

(Source: Das and Mondal, 2013).

Nevertheless, an important factor affecting $\mathrm{AD}$ process is temperature (Ahring, 1994; Cheunbarn and Pagilla, 2000). Generally AD process is operated under mesophillic or thermophillic condition in which thermophillic digestion is reported as more efficient method (Griffin et al., 1998; Ahring et al., 2001). Compared with wet AD process, dry AD process is much beneficial to compact digester with high organic loading rate and it's energetically effective performance (Pawan et al., 2000, Kuroshima et al., 2001). Literature review shows that India stands second in the production of fruits and vegetables in the world. It contributes about 10 and $14 \%$ of fruit and vegetable in the world production. Vegetable wastes are created by marketing, processing, harvesting, transportation etc., that deteriorate easily and cause foul smelling. Many researchers studied anaerobic digestion of vegetable wastes in one stage systems in laboratory scale reactors.

\section{Animal feed}

The amount of commercially produced food waste, on both the large and small scale, needs to be reduced. With nearly $50 \%$ of this waste was derived from fruit and vegetable origins. Fruit and vegetable processing by-/coproducts are promising sources of valuable results have been given in Table 3 .

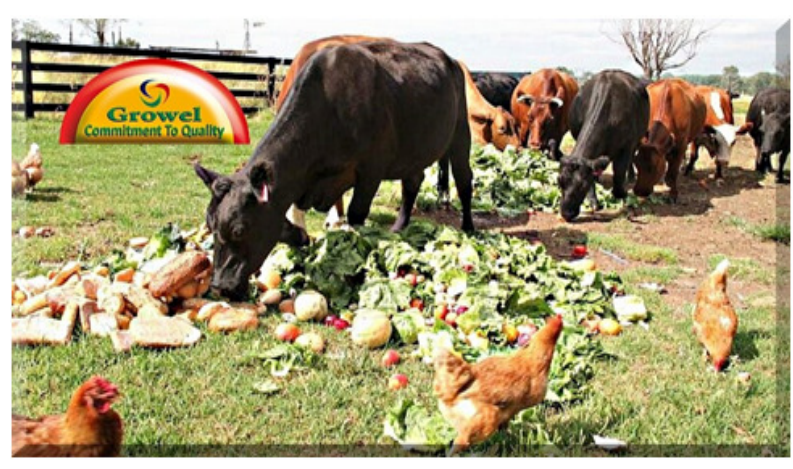

Fig. 3: Cows feeding on fruit and vegetable wastes

substances such as phytochemicals (carotenoids, phenolics, and flavonoids), antioxidants, antimicrobials, vitamins, or dietary fats that possess favorable technological activities or nutritional properties (Schieber et al., 2001, Fernández-López et al., 2008). Already there is a considerable shortage of feed availability in most developing countries. Taking some examples from Asian countries, Bangladesh faces a deficit of 49.4 and 81.9 percent of roughages and concentrates (Uddin, 2013), while in Pakistan a shortage of 43.9, 49.7 and 44.2 percent of dry matter (DM), crude protein (CP) and total digestible nutrients (TDN), respectively has been recorded (Habib, 2008). In China, there was a deficit of 10,30 and 20 million tonnes of protein feed, energy feed, and aquatic feed, respectively (Jie, 2012), and in India a shortage of 25, 159 and 117 million tonnes of concentrates, green forages and crop residues, constituting respectively a shortage of 32, 20 and 25 percent of the requirement has been estimated (Ravi Kiran et al., 2012). The area under fodder production cannot be increased due to increasing human population and urbanization and the industrial intensive model of livestock production has severe limitations due to increasing cost of fossil fuels, competition for food-feed-fuel and other 
biophysical limiting factors. The global price of feed ingredients such as maize, wheat, fish meal and soybean meal has increased by 160, 118, 186 and 108 percent, respectively in the last decade, while the price rise in livestock products such as poultry meat, pork and lamb was only 59,32 and -37 percent respectively, while that of beef was 142 percent (Index Mundi, 2013).

Under these conditions, to meet the nutrient requirements of livestock and to sustain their productivity and profitability seem only possible if non-conventional, alternate feed resources are explored. Plant materials exposed to various physical and chemical treatments for the extraction of economically important components can be characterized as co-products (Serena and Knudsen, 2007). In this respect, citrus pulp - the solid residue that remains after squeezing the fruit for juice-is a by-product, whereas citrus molasses - the syrup produced by the concentration of juice released from the citrus peel-is a co-product. However, there are products such as fermented grape pulp that cannot be classified as either by- or co-products. In terms of animal feeding, the distinction between co- and by-products is not significant and not related to the nutritional value of these products. Therefore, for purposes of convenience, co-/by- products will be referred to as co-products from henceforth.

In accordance to the European Food Safety Authority, feed additives for improved animal product quality can "favorably affect": (a) the sensory characteristics and acceptance of the products, i.e., antioxidants and colorants, (b) the nutritional value of the products, i.e., long chain polyunsaturated fatty acids, conjugated linoleic acid (CLA), and (c) the microbial quality of the products.

Table 4: Functional ingredients from fruit and vegetable processing co-products

\begin{tabular}{|l|c|}
\hline \multicolumn{1}{|c|}{ Fruits And Vegetables } & Fractional Ingredient \\
\hline Apple Skin/Pomace & Polyphenols \\
Orange Peel & Hesperidin \\
Orange Pulp & Carotenoids \\
Grape Pomace/ Skin/ Seeds & Polyphenols \\
Carrot Peel & Polyphenols Carotenoids \\
Tomato Seeds & Unsaturated Fatty Acids \\
Tomato Skin & Carotenoids (Lycopene) \\
Potato Peel & Polyphenols \\
Red Beet & Polyphenols \\
Sunflower Seed & Phytosterols \\
Soybean Seed & Phytosterols \\
Olive Pomace & Polyphenols \\
\hline
\end{tabular}

It is also noted that, according to Article 17 of Regulation (EC) No 1831/2003 on additives for use in animal nutrition, the Commission has established the European Union Register of Feed Additives. Fruit and vegetable co-products are heterogeneous products as their physical form (peels, seeds, stems, stones, pulp etc.), the processing technology of the raw material for the production of the food product, their storage, and handling conditions affect the composition and concentration of the target ingredients. For instance, tomato skins contain higher levels of lycopene in comparison to tomato seeds (Knoblich et al., 2005). Additionally, mechanical peeling of tomatoes with sodium hydroxide increases the sodium content of tomato skins. In 
addition, the names of the co-products (pomace, pulp, cake, waste, etc.) may fail to provide an accurate description of the product ingredients and composition. Therefore, determination of the chemical composition of the co-product before application in livestock diets is suggested. Some typical functional ingredients from fruit and vegetable co-products suitable for application in farm animal nutrition are presented in Table 4 (Galanakis, 2002 and Oreopoulou and Tzia, 2007).

\section{Production of value added products}

The huge quantity of fruit and vegetable wastes and by-products produced throughout the world, both in the organized and un-organized sectors can be effectively utilized. These resources, i.e. peels, pomace and seeds etc. are rich sources of bioactive compounds, which can be extracted and utilized in food, cosmetic, pharmaceutical, and bio-fuel industries. Some of such novel value-added products and their utilities are discussed below.

- Essential oils: The citrus peels are a potential source of essential oil (EO) and yield 0.5 to $3.0 \mathrm{~kg}$ oil/tonnes of fruit. Citrus EO is widely used in alcoholic beverages, confectioneries, soft drinks, perfumes, soaps, cosmetics and household products owing to its aromatic flavor. It also serves as a masking agent in pharmaceutical products (Njoroge et al., 2005). It improves the shelf-life and the safety of fresh fruits (Lanciotti et al., 2004), skim milk and lowfat milk (Dabbah et al., 1970) and exhibits broad spectrum antibacterial activity (Javed et al., 2011). Oils from both sweet and bitter oranges are used in tea formulations and as an ingredient in stomachic, carminative and laxative preparations. Lemon EO contains D-limonene, which improves the immunity, counters occasional feelings of depression, promotes clarity of thought and purpose, energizes and stimulates the mind and body, opens and releases emotional blocks and supports skin health and reduces the appearance of wrinkles (Falsetto, 2008). Dried bitter orange oil is used in treating prolapse of the uterus and rectum, diarrhea and piles.

- Polyphenolic compounds: The concentration of total phenolic compounds in the peels, pulp/pomace and seeds of citrus fruits, apples, peaches, pears, yellow and white flesh nectarines, banana, pomegranate, mulberry, blackberry, tomatoes and sugar beet etc. is more than twice the amount present in edible tissue. Apple and grape pomace are rich in proanthocyanidins and flavonoids, banana in catechin and gallocatechin, carrot pomace in hydroxycinnamic derivatives like chlorogenic acid and dicaffeoylquinic acids (Zhang and Hamauzu, 2004), mango seed kernels (Puravankara et al., 2000) and mango peels (Larrauri et al., 1996) in gallic and ellagic acids. Kinnow peel, litchi pericarp, litchi seeds and grape seeds can serve as potential sources of antioxidants for use in food and pharmaceutical industries. The beet root pomace is a rich source of flavonoids (Čanadanović et al., 2011). The phenolic portion of the beet root peel depicts 1-tryptophane, p-coumaric and ferulic acids, as well as cyclodopa glucoside derivatives. The polyphenolic compounds exhibit anti-cancer, antimicrobial (pathogens), anti-oxidative and immune-modulatory effects in vertebrates. The peel and pulp of guava fruits could be used as a source of antioxidant dietary fibre (Jimenez-Escrig et al., 2001). Polyphenols reduce incidence of cardiovascular diseases and are thought to inhibit oxidation of LDL (Rice-Evans, 2001). Polyphenols can reduce the systolic pressure and the level of plasma cholesterol in humans and animals, 
inhibit platelet aggregation and prevent thrombosis. The terpenoid and flavonoids in banana foliage exhibit anthelmintic properties (Marie-Magdeleine et al., 2010).

- Edible oils: The fat in mango seed kernel is a promising source of edible oil and its fatty acid and triglyceride profiles are similar to those of cocoa butter. Guava (Psidium guajava L., Myrtaceae) seeds, usually discarded during processing of juice and pulp, contain 5-13 percent oil rich in essential fatty acids (Adsule and Kadam, 1995). The passion fruit seed oil is rich in unsaturated fatty acids (87.6 percent), mainly linoleic (73.1 percent) and oleic (13.8 percent) acids (Malacrida and Jorge, 2012). The oil has free radical scavenging activity.

- Pigments. Tomato peel is a rich source of carotenoids such as lycopene (Knoblich et al., 2005). It may be beneficial in curing cancer, coronary heart disease and other chronic conditions. The addition of tomato peel to meat products can result in a healthier product due to both the lycopene and fibre present in this by-product of tomato processing. Carrot pomace is also a good source of carotenoids (Zhang and Hamauzu, 2004). Anthocyanin pigments in banana bracts (leaves below calyx) and beet root pulp were evaluated for their potential application as natural food colorants. The beet root pomace contains $11-23 \mathrm{mg} \beta$ xanthins/g of dry extract (Čanadanović et al., 2011) .Beet root peel is a potential source of valuable water-soluble nitrogenous pigments, called betalains, which comprise two main groups, the red betacyanins and the yellow betaxanthins. They are free radical scavengers and prevent active oxygen-induced and free radical-mediated oxidation of biological molecules. Betalains have been extensively used as natural colorants in the modern food industry (Azeredo, 2009).

- Food additives: Carrot pomace can be used in bread (Osawa et al., 1994), cake, dressing and pickles (Osawa et al., 1995), and in functional drinks; and onion pomace in snacks. In the food industry, synthetic antioxidants, such as butylated hydroxyanizole (BHA) and butylated hydroxytoluene (BHT), have long been widely used as antioxidant additives to preserve and stabilise the freshness, nutritive value, flavour and colour of foods. However, Schilderman et al. (1995) revealed that BHT could be toxic, especially at high doses. Therefore, interest in the substitution of synthetic food antioxidants by natural ones has increased over the recent years. The antioxidant compounds from waste products of the food industry could be used for protecting the oxidative damage in living systems by scavenging oxygen free radicals, and also for increasing the stability of foods by preventing lipid per-oxidation.

- Fermented edible products. A number of beverages such as cider, beer, wine and brandy, and vinegar can be obtained from the fermentation of fruit wastes. Apple pomace has been utilized for the production of cider. The possibility of making brandy from dried culled and surplus apples, grapes, oranges and other fruits has also been explored. Vinegar can also be prepared from fruit wastes. The fruit waste is initially subjected to alcoholic fermentation by acetic acid fermentation by Acetobacter bacteria, which produce acetic acid. Vinegar production by fermenting waste from pineapple juice and orange peel juice has been reported. Apple pomace extract can also be mixed with molasses in 
the ratio of 2:1 for producing vinegar (Gautam and Guleria, 2007).

\section{Conclusion}

Recently, there has been great social and environmental pressure for the efficient reutilization of agricultural industry residues due to the global intensification of food production that has led to the creation of large quantities of food co-products and wastes. The huge wastage of the food material is due to lack of control on such agri-economy practices. By-products from food industries are rich in nutrients so have many health benefits. These by-products are the good source of bioactive compounds, nutraceuticals, and other functional foods. By-products utilization gives another source of income to industries, so it helps to increase economic productivity. So, methods described above are some of the easy techniques which utilize the maximum wastage of fruits and vegetables of industries or households. Some of the advantages of waste utilization concluded from the above methods are:

- Prevention of environmental pollution.

- Good supplement of nutrition for the human population.

- Different types of value added products can be prepared.

- Help in solving the problem of food scarcity.

- Good source of nutrients and can increase fertility of the soil.

- Solve the problems of salinity hazards.

- Can increase economic returns of the industry.

\section{References}

1. Adsule, R.N. and Kadam, S.S. (1995). Guava. In D.K. Salunkhe and S.S. Kadam, eds. Handbook of Fruit Science and Technology, pp. 419-433. Marcel Dekker, New York, Basel, Hong Kong.

2. Ahring, B. K. (1994). Status on science and application of thermophilic anaerobic digestion. Water Science \& Technology, 30: 241-299.

3. Ahring, B.K., Mladenovska, Z. and Iranpour, R. (2001). State of the art and future perspectives of thermophilic anaerobic digestion. Anaerobic Digestion 2001. In: Proceedings of 9th World Congress, Antwerpen, Belgium (Velsen A F M, Verstraete W H ed.). Part 1, 455460.

4. Azeredo, H.M. (2009). Betalains: properties, sources, applications, and stability - a review. International Journal Food Science and Technology, 44: 2365-2376.

5. Baere, L.D. (2000). Anaerobic digestion of solid waste: state-of-the-art. Water Science \& Technology, 41, 283-290.

6. Čanadanović-Brunet, J.M., Savatović, S.S., Ćetković, G.S., Vulić, J.J., Dj ilas, S.M., Markov, S.L. and Cvetković, D.D. (2011). Antioxidant and antimicrobial activities of beet root pomace extracts. Czech Journal of Food Science, 29: 575585.

7. Cheunbarn, T. and Pagilla, K.R. (2000). Anaerobic thermophilic/mesophilic dualstage sludge treatment. Journal of Environmental Engineering, ASCE, 126: 796-801.

8. Christ, O., Wilderer, P.A. and Angerhofer, R. (2000). Mathematical modeling of the hydrolysis of anaerobic processes. Water Science \& Technology, 41(3):61-65.

9. Dabbah, R., Edwards, V.M. and Moats, W.A. (1970). Antimicrobial Action of Some Citrus Fruit Oils on Selected FoodBorne Bacteria. Applied Environmental Microbiology, 19: 27-31. 
Waste utilization of fruits and vegetables-A review

10. Das, A. and Mondal, C. ( 2013). Studies on the utilization of fruit and vegetable waste for generation of biogas. International Journal of Engineering and Science, 3(9): 24-32.

11. De las Fuentes, L., Sanders, B., Lorenzo, A., Alber, S. (2004). AWARENET: Agro-Food Wastes Minimization and Reduction Network. In Total Food Exploiting Co-Products-Minimizing Waste.-Workshop Report; Total Food Exploiting co-products-Minimizing waste; Proceedings Volume; Waldron, K.W., Faulds, C.B., Smith, A.C., Eds.; Institute of Food Research: Norwich, UK, 2004; pp. 233-244.

12. Falsetto, S. (2008). Lemon essential oil, the uses and properties of lemon oil in aromatherapy. Natural Medicine. Suite 101. MHTML document.

13. Fernández-López, J., Sendra, E., SayasBarberá, E., Navarro, C., Pérez-Alvarez, J.A. (2008). Physico-chemical and microbiological profiles of "salchich" (Spanish dry-fermented sausage) enriched with orange fiber. Meat Science, 80: 410 417.

14. Galanakis, C.M. (2012). Recovery of high added-value components from food wastes: Conventional, emerging technologies and commercialized applications. Trends in Food Science and Technology, 26: 68-87.

15. Gautam, H.R. and Guleria, S.P.S. (2007). Food and vegetable waste utilization, Science Tech Enterpreneur, January, 2007.

16. Griffin, M.E., McMahon, K.D., Mackie, R.I. (1998). Methanogenic population dynamics during start-up of anaerobic digesters treating municipal solid waste and biosolids. Biotechnology and Bioengineering, 57: 342-355.
17. Habib, G. (2008). Best practices in animal feed production and management in Pakistan. In Shadidul Huque, Wais Kabir \& Nasrin Akter eds. Best Practices in Animal Feed Production and Management in SAARC Countries. SAARC Agriculture Centre, Khaka-1215, Bangladesh.

18. Index Mundi. (2013). Commodity Price Indices. www.indexmundi.com / commodity.

19. Javed, S., Javaid, A., Mahmood, Z., Javaid, A. and Nasim, F. (2011). Biocidal activity of citrus peel essential oils against some food spoilage bacteria. Journal of Medicinal Plants Research, 5: 3697-3701.

20. Jie, C. (2012). Aquatic feed industry under tension in world and China's grain supply and demand. China Fisheries, 6: 32-34.

21. Knoblich, M., Anderson, B. and Latshaw, D. (2005). Analyses of tomato peel and seed byproducts and their use as a source of carotenoids. Journal Science Food Agriculture, 85, 1166-1170.

22. Knoblich, M., Anderson, B. and Latshaw, D. (2005). Analysis of tomato peel and seed byproduct and their use as a source of carotenoids. Journal of the Science of Food and Agriculture, 85: 1166-1170.

23. Kuroshima, M., Misaki T. and Ishibashi, T. (2001). Dry anaerobic treatment of livestock waste together with municipal solid waste. In: Proceedings of 9th World Congress, Antwerpen, Belgium (Velse A. F. M., Verstratete W.H.,ed.). Part 1, 375380 .

24. Lanciotti, R., Gianotti, A., Patrignani, F., Belletti, N., Guerzoni, M. E. and Gardini, F. (2004). Use of natural aroma compounds to improve shelf life and safety of minimally processed fruits. Trends in Food Science and Technology, 15: 201-208. 
25. Larrauri, J.A., Ruperez, P. and SauraCalixto, F. 1996. Antioxidant activity from wine pomace. American Journal of Enology and Viticulture, 47: 369-372.

26. Malacrida, C.R. and Jorge, N. (2012). Yellow passion fruit seed oil (Passiflora edulis $f$. flavicarpa): physical and chemical characteristics. Brazilian Archives of Biology and Technology, 55 (1):127-134.

27. Marie-Magdeleine, C., Boval, M., Philibert, L., Borde, A. and Archimede, H. (2010). Effect of banana foliage (Musa paradisiaca) on nutrition, parasite infection and growth of lambs. Livestock Science, 131: 234-239.

28. Mata, A.J., Mace, S. and Llabres, P. (2000). Anaerobic digestion of organic solid wastes. An overview of research achievements and perspectives. Bioresource Technology, 74(1): 3-16.

29. Njoroge, S.M., Koaze, H., Karanja, P.N. and Sawamura, M. (2005). Volatile constituents of redblush grapefruit (Citrus paradisi) and pummel (Citrus grandis) peel essential oils from Kenya. Journal of Agriculture and Food Chemistry, 53: 9790-9794.

30. Oreopoulou, V. and Tzia, C. (2007). Utilization of plant by-products for the recovery of proteins, dietary fibers, antioxidants, and colorants. In Utilization of by-Products and Treatment of Waste in the Food Industry; Oreopoulou, V., Winfried, R., Eds.; Springer: New York, NY, USA, pp. 209-232.

31. Osawa, K., Chinen, C., Takanami, S., Kuribayashi, T. and Kurokouchi, K. (1994). Studies on effective utilisation of carrot pomace. I. Effective utilization to bread. Research Report of the Nagano State Laboratory of Food Technology, 22: $24-28$.
32. Osawa, K., Chinen, C., Takanami, S., Kuribayashi, T. and Kurokouchi, K. (1995). Studies on effective utilisation of carrot pomace. II. Effective utilisation to cake, dressings and pickles. Research Report of the Nagano State Laboratory of Food Technology, 23: 15-18.

33. Pavan, P., Battistoni, P., Mata, A.J. (2000). Performance of thermophilic semi-dry anaerobic digestion process changing the feed biodegradability. Water Science \& Technology, 41: 75-81.

34. Puravankara, D., Boghra, V. and Sharma, R.S. (2000). Effect of antioxidant principles isolated from mango (Mangifera indica L.) seed kernels on oxidative stability of buffalo ghee (butterfat). Journal of the Science of Food and Agriculture, 80: 522-526.

35. Ravi Kiran, G., Suresh, K.P., Sampath, K.T., Giridhar, K. and Anandan, S. (2012). Modeling and Forecasting Livestock and Fish Feed Resources: Requirements and Availability in India. National Institute of Animal Nutrition and Physiology, Bangalore.

36. Rice-Evans, C. (2001). Flavonoid Antioxidants. Current Medicinal Chemistry, 8: 797-807.

37. Sagagi, B.S., Garba, B. and Usman, N.S. (2009) studies on biogas production from fruits and vegetables waste. Bayero Journal of Pure and Applied Science, 2: 115-118.

38. Schieber, A., Stintzing, F.C., Carle, R. (2001). By-products of plant food processing as a source of functional compounds-Recent developments. Trends in Food Science \& Technology, 12: 401-413.

39. Schilderman, P.A.E.L., Vaaewerk, F.J., Lutgerink, J.T., Van der Wurf, A., Hoor, F. and Kleinjans, J. (1995). Induction of oxidative DNA damage and early lesions 
Waste utilization of fruits and vegetables-A review

in rat gastro-intestinal epithelium in relation to prostaglandin $\mathrm{H}$ synthasemediated metabolism of butylated hydroxyanisole. Food and Chemical Toxicology, 33: 99-109.

$\begin{array}{ll}\text { Received } & \text { : Feb, 2018 } \\ \text { Revised } & \text { : April., 2018 } \\ \text { Published } & \text { : June, } 2018\end{array}$

40. Serena, A. and Knudsen, K.E. (2007). Chemical and physicochemical characterization of co-products from the vegetable food and agro industries. Animal Feed Science and Technology. 2007, 139, 109-124.

41. Uddin, M.M. 2013. Feed inventory in Bangladesh, preliminary data (Personal communication).

42. Uzodinma, E.O., Ofoefule, A.U. and Enwere, N.J. (2011). Optimization of biogas fuel production from maize bract waste: comparative study of biogas production from blending maize bract with biogenic waste. American Journal of Food and Nutrition, 1(1):1-6.

43. Vavilin, V.A., Rytov, S.V. and Lokshina, L.Y. (1996). A description of the hydrolysis kinetics in anaerobic degradation of particulate organic matter. Bioresource Technology, 56: 229-237.

44. Veeken, A., Kalyuzhnyi, S., Scharff, H. and Hamelers, B. (2000). Effect of $\mathrm{pH}$ and VFA on hydrolysis of organic solid waste. Journal of Environmental Engineering, ASCE, 126: 1076-1081.

45. Wantanee, A. and Sureelak, R. (2004). Laboratory scale experiments for biogas production from cassava tubers. In: the joint international conference on "sustainable energy and environment (SEE)" held during Dec 1-3 at Thailand.

46. Zhang, D. and Hamauzu, Y. (2004). Phenolic compounds and their antioxidant properties in different tissues of carrots. Food Agriculture and Environment, 2: 95-100. 